\title{
Value Creation and Competitive Advantage: Empirical Evidence from Dividend Champions of the S\&P 500
}

\author{
Marina Damilano ${ }^{1}$, Nicola Miglietta ${ }^{1}$, Enrico Battisti ${ }^{1} \&$ Fabio Creta $^{1}$ \\ ${ }^{1}$ School of Management and Economics, University of Turin, Turin, Italy \\ Correspondence: Enrico Battisti, School of Management and Economics, University of Turin, Turin, Italy. E-mail: \\ enrico.battisti@unito.it
}

Received: September 28, 2018

Accepted: October 25, 2018

Online Published: November 12, 2018

doi:10.5539/ijbm.v13n12p50

URL: https://doi.org/10.5539/ijbm.v13n12p50

\begin{abstract}
The aim of the paper is to verify, through the measurement of value creation, the existence of a competitive advantage in those companies recognized as "Dividend Champions" in the S\&P 500. The paper uses a quantitative and explorative method of research and is divided into two sections: in the first, it identifies, within the S\&P 500, those companies that have systematically, for more than 40 years, distributed dividends that have grown each year (60 firms), and in the second, it gives a comparative analysis of the Return on Invested Capital and Weighted Average Cost of Capital of the analysed firms, in order to investigate the existence of a competitive advantage. The results of our research show that the "Dividend Champions" have, in comparison to their main competitors of reference in the US market, a lasting competitive advantage, in virtue of a higher profitability with respect to the cost of capital. Specifically, we can observe that the "Dividend Champions", classified by sector, are also "Value Champions", able to beat competitors and having a lasting competitive advantage.
\end{abstract}

Keywords: corporate finance, "dividend champions", lasting competitive advantage, "value champions", value creation, S\&P 500

\section{Introduction}

Corporate finance scholars agree that the goal of a company is to maximize value (Berk and DeMarzo, 2012; Blyth et al., 1986; Brealey et al., 2015; Dallocchio and Salvi, 2011; Damodaran, 2015; Ferrero, 1981; Guatri, 1991; Jensen, 2001; Tardivo et al., 2010; Miglietta et al., 2018b). More controversial is whether this leads to the maximization of the value of the share price (shareholder value), the value of the firm (firm value) or the value of the equity (equity value) (which considers, in addition to shareholders, other stakeholders). However, most of the theoretical models of corporate finance assume that the main objective is, for listed companies, the maximization of the share price (stock price) (Damodaran, 2015).

From this point of view, the main strategies that define value are based on both internal developments (related to the exploration and selection of strategic and operational opportunities within the company) and external developments (e.g. mergers and acquisitions, and joint ventures).

There are numerous references in the literature that associate a company's creation of value over time, measured by appropriate indices such as ROIC (Return on Invested Capital) and WACC (Weighted Average Cost of Capital), with the presence of a lasting competitive advantage (Adams and Thornton, 2009; Bughin and Copeland, 1997; Copeland, 2002a, b; Hawawini et al., 2002). Concretely, the creation of value for shareholders requires a competitive advantage because otherwise, as noted by Rappaport (1986), it would not be possible to achieve a greater return than the cost of capital, or any extra profit.

In this regard, the aim of this work is to investigate, through the measurement of value creation, the existence of a competitive advantage in the so-called "Dividend Champions" within the S\&P 500. We carried out the work in two main parts: first, we identified the companies in the Standard \& Poor 500 that are classified as "Dividend Champions" (companies that have been systematically distributing increasing dividends for over 40 years), and, second, we ran a comparative analysis between the ROIC and the WACC of those companies, in order to investigate their ability to create value and, consequently, to discover the existence of a lasting competitive advantage, also compared to their main competitors.

In particular, the contribution of this work is double: i) we have highlighted the existence of a lasting competitive 
advantage in the companies in the US market defined as "Dividend Champions", classified by sector; and ii) we have shown the existence, for the same companies, of higher value creation than their respective competitors, which is typical of companies classified as "Value Champions".

The remainder of this research is organized as follows. Section 2 proposes the literature review of the paper regarding value creation and competitive advantage. Section 3 explains the methodological approach, while Section 4 describes the finding of our study. Finally, Section 5 presents a concluding discussion identifying implications for theory and practice, limits and future lines of research.

\section{Literature Review}

\subsection{Value Creation}

As previously mentioned, the leading corporate finance scholars agree that the goal of a company is to maximize value (Brealey et al., 2015; Damodaran, 2015; Jensen, 2001). The type of value, however, is more debated and, in literature, this topic is particularly controversial (Damodaran, 2001, Watson and Head, 2016). In fact, there are other objectives that a company could decide to pursue: market share, profit maximization, company size, or customer satisfaction. However, none of the latter meets the requirements that an objective must possess: it must be clearly defined or definable, be measurable with certainty and timeliness, and not be in conflict with social interests (Tardivo et al., 2010). Furthermore, only the maximization of value is able to guide financial decisions and to support the construction of a coherent integrated process required by a theoretical model. Consequently, most of the theoretical models in corporate finance assume for three main reasons that the main objective of a company is to maximize shareholder value (Damodaran, 2001):

- the price of shares is a parameter that can be immediately and continuously assessed;

- share prices reflect the long-term effects of company policies; and

- the share price is a clear criterion for choosing investment projects and financing methods and evaluating the effects of these choices.

However, even the above-mentioned objective is not free from criticism if the social costs created as a result are higher than the benefits generated.

In the literature there are different interpretations of dividends in relation to the creation of value. The classical theory (e.g. Black and Scholes, 1974, Jose and Stevens, 1989; Modigliani and Miller, 1961; Miller and Scholes, 1978) states that dividends are irrelevant and that the distribution of dividends does not affect the value of the company. Underlying the theory of the irrelevance of dividends is the principle that if a stock pays a dividend, it will have a correspondingly lower value for the shareholder, while the total return will remain unchanged and will continue to represent the risk of the stock, linked to the investment policies and their ability to generate cash flow. However, several scholars (e.g. Baker et al., 1985; 2001; Benartzi et al., 1997; Bhattacharya, 1979; Fama and Babiak, 1968; Farrelly et al., 1986 Healy and Palepu, 1988; Lintner, 1956; Watts, 1973; Pruitt and Gitman, 1991) have shown that firms continue to pay dividends and that many investors react positively to this policy. From this point of view, the value of a company is influenced by its dividend distribution policy.

\subsection{Competitive Advantage}

In the literature there is no agreement on the definition of competitive advantage (e.g. Ghemawat, 1991; Pellicelli, 2014; Pivato et al., 2004). According to some management scholars, competitive advantage is "the ability to stand out positively, when compared to competitors, in the buyer perception" (Pellicelli, 2014). Concretely, from an economic point of view, a company obtains a competitive advantage when it reaches "a higher profitability than the sector average" (Kay, 1993); this profitability is defined by two indices, Return on Assets (ROA) and Return on Sales (ROS). Grant (1995) emphasizes the aspect of sustainability, by defining competitive advantage as "the condition that would allow companies a lasting superiority in their economic results". According to Rappaport (1986), a company creates a competitive advantage if "the long-term value of its output, or its sales, is greater than the total costs, including the cost of capital". Fontana and Caroli (2009) reveal the strategic aspect connected to the attainment of a competitive advantage and define it as "the result of a strategy that leads the company to occupy and maintain a favourable position in the market (or, more generally, in the environment) in which it operates and which translates into a permanently higher profitability than the average of competitors".

Companies that produce high quality goods or that innovate more and in a better way than others have a competitive advantage; however, they may have a lower profitability than the average of their competitors because their prices are too low or their costs of production too high.

In this regard, given that some companies are able to achieve results that are above the industry average, it is 
important to highlight that some companies have a competitive advantage and others do not. The profitability of a company is linked to the structure of the sector and the ability of the company, compared to its rivals, to create greater value for the customer (a consumer surplus for the buyer). In particular, in order to obtain a competitive advantage, a company must not only create positive value for its customers (benefit that is greater than the price), but must also create more value for its customers than its rivals (Argote and Ingram, 2000; Grant, 1999; Hall, 1993; Pellicelli, 2014). In this sense, a company gains a competitive advantage only if it is able to create greater value than its competitors. Generally, in order to obtain a competitive advantage, an enterprise must (Porter, 1998):

- pursue a significant cost advantage over its competitors (cost leadership);

- be able to differentiate products in order to apply higher prices than its competitors (differentiation); and

- concentrate its resources on a particular group of buyers, market or product line, outdoing its competitors on cost or differentiation.

In particular, a company is a cost leader if it manages to have a significant cost advantage over its competitors. Cost leadership implies efficiency in the use of tangible assets (plant, machinery, and equipment), strong control over fixed costs and the containment of costs in all the company functions. On the other hand, a company that confronts its competitors with products or services with unique characteristics and that is perceived as superior by buyers (in terms of design, brand image, customer services, etc.), will compete on differentiation.

\subsection{Value Creation and Competitive Advantage}

With reference to the existing connections between value creation and competitive advantage, from the literature we can identify multiple factors that are responsible for the competitive advantage of a company and that define its value creation. For example, a high price/book value indicates the presence of an advantage by the company (Lin and Huang, 2011). Tobin's "q" indicator represents the market value, per share package, of a company, and it is able to measure the gap between the desired and the actual capital held. It is calculated as the market value of the company divided by the total cost of its assets (Tobin, 1969). When this indicator is greater than 1, the company has a competitive advantage that can result in a greater return on investment. Return on Assets represents the efficiency with which an organization uses its own resources. If a large proportion of its assets are invested in intangibles rather than physical assets, high ROA values indicate less intensive or "business light" assets. A company with an ROA of less than $5 \%$ is very solid, while one with an ROA of more than $20 \%$ is defined as "asset-light" (Lin and Huang, 2011). An additional indicator that is commonly used to measure competitive advantage is the Return on Equity (ROE), a measure that summarizes the return for shareholders. ROIC is also an important measure of efficiency of earnings, and represents the ability of the management to promote and sustain shareholder value. According to Tang and Liou (2010), this measure of profitability is also an indicator of the presence of competitive advantage in a company.

The possibility of achieving a sustainable competitive advantage over time occurs when the assets, because of the strategies implemented by the company, provide a return on the invested capital greater than the weighted average cost of capital. This yield spread measures the ability of the company to create value. If the ROIC is higher than the WACC, the economic profit, for each unit of capital employed, is positive and the company creates value. The opposite is true when the ROIC is lower than the WACC (Hawawini et al., 2002).

The company must have one of the following competitive advantages so that it can keep its ROIC greater than its WACC, or, in other words, create value (Ubago Vivas, 2014):

- a higher price for its products than its competitors;

- a lower total unit cost than that of its competitors; and

- the ability to sell higher volumes for every unit of invested capital than its competitors.

The relationship between the ROIC and the WACC determines, in the long term, the market value of the company's invested operating capital, and the result allows the future profitability of the company to be estimated. For companies with a ROIC greater than their WACC, the market value of the invested capital should be higher than its book value (Ubago Vivas, 2014). In conclusion, we can affirm that the creation of value for shareholders requires a sustainable competitive advantage, over time, which can be identified by the difference between the ROIC and the WACC.

\section{Methodological Approach}

The research, using a quantitative explorative approach (e.g. Burns, 2000; Punch, 1998), was developed using the following steps: 1) Extraction, from the S\&P 500, of the companies recognized as "Dividend Champions". 2) Measurement of Value Creation (ROIC - WACC) for these companies. 3) Identification of Competitors and their 
average Value Creation in the sector. 4) Comparison between the results for the "Dividend Champions" and the results for their Competitors, classified into sectors in order to investigate the presence of a lasting competitive advantage.

Specifically, the phases were divided into: 1) Extraction of the companies called "Dividend Champions". 2) Classification of these companies into the sectors and sub-sectors to which they belonged. 3) Calculation, for the selected companies, of their ROIC for the last 5 years (2013-2017) and their average ROIC. 4) Calculation, for the same selected companies, of the WACC for the last 5 years (2013-2017) and the average WACC. 5) Calculation of Value Creation, through the relationship between the average ROIC and WACC calculated in points 3) and 4). 6) Identification of Competitors of the "Dividend Champions" classified by sectors, and analysis of the average of ROIC - WACC. 7) Comparative analysis between the Value Creation of the "Dividend Champions" and the average Value Creation of their respective Competitors.

In the first phase, starting from the Standard \& Poor 500, which is the US market index that brings together the 500 listed companies with the highest capitalization, we extracted those companies that, for over 40 consecutive years, had distributed growing dividends (so-called "Dividend Champions"). There were 65 of these companies, and they belonged to a variety of sectors. Because of the objectives of this work, we decided to exclude companies belonging to the financial and insurance sectors. The final sample therefore numbered 60 , or $92 \%$ of the S\&P 500 "Dividend Champions" universe.

In the second phase, the "Dividend Champions" were classified by sector and sub-sector, in order to identify, in the subsequent phases, whether a competitive advantage was present.

In the third and fourth phases, the following indicators were calculated for each of these 60 companies:

- ROIC (Return on Invested Capital): a measure of the company's return on invested capital. This provides an idea of how a company is using its liquidity to generate profitability. It is a useful indicator for an overview of the economic aspects, linked to the profit trends and the invested capital.

Formula:

$$
\text { ROIC = Operating Income }(1-\text { Tax Rate }) / \text { Invested Capital }
$$

Where:

- Operating Income ( 1 - Tax Rate) represents operating income after taxes. Formula: Net Income + Interest Expenses ( 1 - Tax Rate) - Non-operating income ( 1 - Tax Rate).

- Invested Capital (IC) represents the invested capital. Formula: Short-term debt + Long-term debt + Shareholder equity - Cash/equivalents - Goodwill.

- WACC (Weighted Average Cost of Capital): an index that represents the weighted average of the different sources of financing of a company (equity and debt).

Formula:

$$
W A C C=E /(E+D) * \text { Cost of Equity }+D /(E+D) * \text { Cost of Debt }
$$

Where:

○ $\quad \mathrm{E}=$ equity (full risk capital).

○ $\mathrm{D}=$ debt (third-party capital).

- Cost of Equity represents the return required by those who invest capital at full risk. Formula: Risk free rate + Beta levered * Market risk premium.

- Cost of Debt represents the return requested by third-party lenders. Formula: Interest rate * $(1$ - tax rate).

The comparison between a company's return on invested capital and its weighted average cost of capital reveals whether the capital investment is used effectively.

In the fifth phase we carried out a comparative analysis of the average ROIC for the last 5 years (2013-2017), obtained from the average of the individual ROICs from 2013 to 2017, and the average WACC for the last 5 years (2013-2017), at market value, obtained from the average of the individual WACCs calculated from 2013 to 2017. Finally, we estimated the spread determined by the relationship between ROIC and WACC.

In the sixth phase we extrapolated the Competitors of the "Dividend Champions" in the US market (Damodaran Online, 2018) and we classified them by sector.

In the final phase we calculated, for all the Competitors in each sector identified in the previous point, the average ROIC, which we obtained from the average ROIC for the last 5 years (2013-2017), and the average WACC, obtained from the average WACC for the last 5 years (2013-2017). Finally, we compared the "Dividend 
Champions" with the Competitors in order to verify whether there was value creation over time by these companies and to discover whether there was a lasting competitive advantage.

\section{Findings}

The results of our exploratory analysis can be divided into two distinct phases. In the first phase, after classifying the companies by sectors (Tables 1 and 2), calculating the return on invested capital and the cost of capital over the last 5 years (2013-2017), we carried out a comparative analysis between the average return on capital and its weighted average cost (Table 3).

Table 1. List of "Dividend Champions" Classified by Sector and Sub-sector

\begin{tabular}{|c|c|c|c|c|c|}
\hline & Symbol & Name & Yrs & Sector & Sub-Sector \\
\hline 1 & AWR & American States Water & 63 & Utilities (General) & Utilities - Regulated Water \\
\hline 2 & DOV & Dover Corp. & 62 & Diversified & Diversified Industrials \\
\hline 3 & GPC & Genuine Parts Co. & 62 & Apparel & Specialty Retail \\
\hline 4 & NWN & Northwest Natural Gas & 62 & Utilities (General) & Utilities - Regulated Gas \\
\hline 5 & EMR & Emerson Electric & 61 & Diversified & Diversified Industrials \\
\hline 6 & $\mathrm{PH}$ & Parker-Hannifin Corp. & 61 & Diversified & Diversified Industrials \\
\hline 7 & PG & Procter \& Gamble Co. & 61 & Packaging \& Container & Household \& Personal Products \\
\hline 8 & MMM & 3M Company & 60 & Diversified & Diversified Industrials \\
\hline 9 & WC & Vectren Corp. & 58 & Utilities (General) & Utilities - Regulated Gas \\
\hline 10 & KO & Coca-Cola Company & 56 & Beverage (Soft) & Beverages - Soft Drinks \\
\hline 11 & $\mathrm{JNJ}$ & Johnson \& Johnson & 55 & Healthcare Products & Drug Manufacturers - Major \\
\hline 12 & LANC & Lancaster Colony Corp. & 55 & Packaging \& Container & Packaged Foods \\
\hline 13 & LOW & Lowe's Companies & 55 & Apparel & Home Improvement Stores \\
\hline 14 & $\mathrm{CL}$ & Colgate-Palmolive Co. & 54 & Packaging \& Container & Household \& Personal Products \\
\hline 15 & NDSN & Nordson Corp. & 54 & Diversified & Diversified Industrials \\
\hline 16 & HRL & Hormel Foods Corp. & 52 & Packaging \& Container & Packaged Foods \\
\hline 17 & TR & Tootsie Roll Industries & 52 & Packaging \& Container & Confectioners \\
\hline 18 & ABM & ABM Industries Inc. & 51 & Business \& Consumer Services & Business Services \\
\hline 19 & CWT & California Water Service & 51 & Utilities (General) & Utilities - Regulated Water \\
\hline 20 & SJW & SJW Corp. & 51 & Utilities (General) & Utilities - Regulated Water \\
\hline 21 & FRT & Federal Realty Inv. Trust & 50 & R.E.I.T. & REIT - Retail \\
\hline 22 & SWK & Stanley Black \& Decker & 50 & Diversified & Tools \& Accessories \\
\hline 23 & SCL & Stepan Company & 50 & Chemical (Basic) & Specialty Chemicals \\
\hline 24 & TGT & Target Corp. & 50 & Retail (General) & Discount Stores \\
\hline 25 & MO & Altria Group Inc. & 48 & Tobacco & Tobacco \\
\hline 26 & CTWS & Connecticut Water Service & 48 & Utilities (General) & Utilities - Regulated Water \\
\hline 27 & FUL & H.B. Fuller Company & 48 & Chemical (Basic) & Specialty Chemicals \\
\hline 28 & SYY & Sysco Corp. & 48 & Retail (General) & Food Distribution \\
\hline 29 & $\mathrm{BKH}$ & Black Hills Corp. & 47 & Utilities (General) & Utilities - Diversified \\
\hline 30 & NFG & National Fuel Gas & 47 & Oil/Gas Distribution & Oil \& Gas E\&P \\
\hline 31 & UW & Universal Corp. & 47 & Tobacco & Tobacco \\
\hline 32 & BDX & Becton Dickinson \& Co. & 46 & Healthcare Support Services & Medical Instruments \& Supplies \\
\hline 33 & CSVI & Computer Services Inc. & 46 & Computer Services & Information Technology Services \\
\hline 34 & KMB & Kimberly-Clark Corp. & 46 & Packaging \& Container & Household \& Personal Products \\
\hline 35 & LEG & Leggett \& Platt Inc. & 46 & Apparel & Home Furnishings \& Fixtures \\
\hline 36 & MSA & MSA Safety Inc. & 46 & Office Equipment \& Services & Security \& Protection Services \\
\hline 37 & PEP & PepsiCo Inc. & 46 & Beverage (Soft) & Beverages - Soft Drinks \\
\hline 38 & PPG & PPG Industries Inc. & 46 & Chemical (Basic) & Specialty Chemicals \\
\hline 39 & TNC & Tennant Company & 46 & Diversified & Diversified Industrials \\
\hline 40 & GWW & W.W. Grainger Inc. & 46 & Retail (Distributors) & Industrial Distribution \\
\hline 41 & GRC & Gorman-Rupp Company & 45 & Diversified & Diversified Industrials \\
\hline 42 & $\mathrm{HP}$ & Helmerich \& Payne Inc. & 45 & Oil/Gas Distribution & Oil \& Gas Drilling \\
\hline 43 & MSEX & Middlesex Water Co. & 45 & Utilities (General) & Utilities - Regulated Water \\
\hline 44 & SPGI & S\&P Global Inc. & 45 & Brokerage \& Investment Banking & Capital Markets \\
\hline 45 & VFC & VF Corp. & 45 & Apparel & Apparel Manufacturing \\
\hline 46 & WMT & Wal-Mart Inc. & 45 & Retail (General) & Discount Stores \\
\hline 47 & ED & Consolidated Edison & 44 & Utilities (General) & Utilities - Regulated Electric \\
\hline 48 & RPM & RPM International Inc. & 44 & Chemical (Basic) & Specialty Chemicals \\
\hline 49 & ADM & Archer Daniels Midland & 43 & Packaging \& Container & Farm Products \\
\hline 50 & ADP & Automatic Data Proc. & 43 & Business \& Consumer Services & Business Services \\
\hline 51 & ITW & Illinois Tool Works & 43 & Diversified & Diversified Industrials \\
\hline 52 & MCD & McDonald's Corp. & 42 & Restaurant/Dining & Restaurants \\
\hline 53 & MGEE & MGE Energy Inc. & 42 & Utilities (General) & Utilities - Diversified \\
\hline 54 & PNR & Pentair Ltd. & 42 & Diversified & Diversified Industrials \\
\hline 55 & WBA & Walgreens Boots Alliance Inc. & 42 & Retail (General) & Pharmaceutical Retailers \\
\hline 56 & CSL & Carlisle Companies & 41 & Rubber \& Tyres & Rubber \& Plastics \\
\hline 57 & CLX & Clorox Company & 41 & Packaging \& Container & Household \& Personal Products \\
\hline 58 & WGL & WGL Holdings Inc. & 41 & Utilities (General) & Utilities - Regulated Gas \\
\hline 59 & MDT & Medtronic plc & 40 & Healthcare Products & Medical Devices \\
\hline 60 & SHW & Sherwin-Williams Co. & 40 & Chemical (Basic) & Specialty Chemicals \\
\hline
\end{tabular}


Table 2. Percentage composition of the ""Dividend Champions" classified by sector

\begin{tabular}{|c|c|c|c|c|c|c|c|c|c|c|c|c|c|}
\hline Sector & \multicolumn{11}{|c|}{ Dividend Champions } & TOT $N^{\circ}$ & TOT\% \\
\hline Utilities (General) & AWR & NWN & VVC & CWT & SJW & CTWS & BKH & MSEX & ED & MGEE & WGL & 11 & $18.33 \%$ \\
\hline Diversified & DOV & EMR & PH & MMM & NDSN & SWK & TNC & GRC & ITW & PNR & & 10 & $16.67 \%$ \\
\hline Packaging \& Container & PG & LANC & $\mathrm{CL}$ & HRL & TR & KMB & ADM & CLX & & & & 8 & $13.33 \%$ \\
\hline Chemical (Basic) & $\mathrm{SCL}$ & FUL & PPG & RPM & SHW & & & & & & & 5 & $8.33 \%$ \\
\hline Retail (General) & TGT & SYY & WMT & WBA & & & & & & & & 4 & $6.67 \%$ \\
\hline Apparel & LEG & VFC & GPC & LOW & & & & & & & & 4 & $6.67 \%$ \\
\hline Beverage (Soft) & $\mathrm{KO}$ & PEP & & & & & & & & & & 2 & $3.33 \%$ \\
\hline Business \& Consumer Services & $\mathrm{ABM}$ & ADP & & & & & & & & & & 2 & $3.33 \%$ \\
\hline Tobacco & MO & UVV & & & & & & & & & & 2 & $3.33 \%$ \\
\hline Healthcare Products & $\mathrm{JNJ}$ & MDT & & & & & & & & & & 2 & $3.33 \%$ \\
\hline Oil/Gas Distribution & NFG & $\mathrm{HP}$ & & & & & & & & & & 2 & $3.33 \%$ \\
\hline R.E.I.T. & FRT & & & & & & & & & & & 1 & $1.67 \%$ \\
\hline Healthcare Support Services & BDX & & & & & & & & & & & 1 & $1.67 \%$ \\
\hline Computer Services & CSVI & & & & & & & & & & & 1 & $1.67 \%$ \\
\hline Office Equipment \& Services & MSA & & & & & & & & & & & 1 & $1.67 \%$ \\
\hline Retail (Distributors) & GWW & & & & & & & & & & & 1 & $1.67 \%$ \\
\hline Brokerage \& Investment Banking & SPGI & & & & & & & & & & & 1 & $1.67 \%$ \\
\hline Restaurant/Dining & MCD & & & & & & & & & & & 1 & $1.67 \%$ \\
\hline Rubber \& Tyres & CSL & & & & & & & & & & & 1 & $1.67 \%$ \\
\hline & & & & & & & & & & & & 60 & $100 \%$ \\
\hline
\end{tabular}

Table 3. ROIC and WACC Analysis (2013-2017) of the "Dividend Champions"

\begin{tabular}{|c|c|c|c|c|c|c|c|c|c|c|c|c|c|}
\hline Symbol & \begin{tabular}{|l|} 
Roic $2013(\%)$ \\
\end{tabular} & Roic $2014(\%)$ & \begin{tabular}{|l|l|} 
Roic $2015(\%)$ \\
\end{tabular} & \begin{tabular}{|l|l|} 
Roic 2016(\%) \\
\end{tabular} & \begin{tabular}{|l|} 
Roic 2017(\%) \\
\end{tabular} & Average Roic (\%) & Wacc $2013(\%)$ & $\mid$ Wacc $2014(\%)$ & Wacc $2015(\%) \mid \mathrm{V}$ & Wacc $2016(\%) \mid v$ & |Wacc $2017(\%)$ & Average Wacc $(\%)$ & \begin{tabular}{|l|l|} 
Roic-Wacc (\%) \\
\end{tabular} \\
\hline 1 AWR & 9.76 & 9.50 & 9.31 & 8.45 & 8.38 & $\begin{array}{l}.08 \\
\end{array}$ & $\begin{array}{ll}6.02 \\
\end{array}$ & 8.65 & \begin{tabular}{|l|l|}
6.54 \\
\end{tabular} & \begin{tabular}{|l|}
2.84 \\
\end{tabular} & 1.44 & \begin{tabular}{|l|}
5.10 \\
\end{tabular} & 3.98 \\
\hline 2 DOV & 12.37 & 12.85 & 11.34 & 8.05 & 10.68 & 11.06 & 9.94 & 8.22 & 8.39 & 8.70 & 8.32 & 8.71 & 2.34 \\
\hline $3 \mathrm{GPC}$ & 19.57 & 18.19 & 18.80 & 18.47 & 12.18 & 17.44 & 6.41 & 5.86 & 8.81 & 8.95 & 8.09 & 7.62 & 9.82 \\
\hline 4 NWN & 5.16 & 5.03 & 4.53 & 5.05 & 5.62 & 5.08 & 4.51 & 4.67 & 4.07 & 4.05 & 3.21 & 4.10 & 0.98 \\
\hline 5 EMR & 19.27 & 18.39 & 16.47 & 15.82 & 17.25 & 17.44 & 9.57 & 8.90 & 7.81 & 7.05 & 9.04 & 8.47 & 8.97 \\
\hline \begin{tabular}{l|l|}
6 & $\mathrm{PH}$ \\
\end{tabular} & 15.80 & 13.72 & 16.52 & 14.67 & 13.08 & 14.76 & 11.33 & 11.95 & 11.43 & 8.48 & 8.74 & 10.39 & 4.37 \\
\hline 7 PG & 11.88 & 11.61 & 11.15 & 12.84 & 14.55 & 12.41 & 4.17 & 4.37 & 7.31 & 4.90 & 5.14 & 5.18 & 7.23 \\
\hline $8 \mathrm{MMM}$ & 23.82 & 27.18 & 26.41 & 25.66 & 22.84 & 25.18 & 9.58 & 8.93 & 8.80 & 7.88 & 7.56 & 8.55 & 16.63 \\
\hline 9 wc & 6.53 & 6.35 & 7.21 & 7.09 & 6.96 & 6.83 & 4.49 & 5.59 & 6.40 & 5.63 & 5.22 & 5.47 & 1.36 \\
\hline \begin{tabular}{|l|l|}
$10 \mathrm{KO}$ \\
\end{tabular} & 15.46 & 14.70 & 15.61 & 16.23 & 3.56 & 13.11 & 3.96 & 5.64 & 6.18 & 5.76 & 4.75 & 5.26 & 7.85 \\
\hline 11 JNJ & 26.73 & 28.09 & 26.84 & 32.61 & 2.09 & 23.27 & 5.86 & 7.06 & 7.89 & 6.22 & 5.86 & 6.58 & 16.69 \\
\hline 12 LANC & 27.70 & 29.16 & 28.47 & 30.65 & 27.72 & 28.74 & 5.27 & 5.67 & 8.86 & 8.02 & 7.79 & 7.12 & 21.62 \\
\hline 13 LOW & 9.85 & 11.72 & 14.22 & 14.20 & 16.93 & 13.38 & 8.00 & 8.42 & 8.90 & 7.07 & 8.56 & 8.19 & 5.19 \\
\hline $14 \mathrm{CL}$ & 38.20 & 31.97 & 36.51 & 49.35 & 44.43 & 40.09 & 4.52 & 6.17 & 7.05 & 6.09 & 6.07 & 5.98 & 34.11 \\
\hline 15 NDSN & 16.60 & 16.21 & 13.51 & 16.72 & 14.57 & 15.52 & 10.38 & 8.94 & 9.39 & 8.91 & 9.43 & 9.41 & 6.11 \\
\hline 16 HRL & 19.14 & 18.04 & 18.18 & 20.77 & 18.21 & 18.87 & 6.45 & 6.60 & 7.85 & 4.83 & 3.41 & 5.83 & 13.04 \\
\hline 17 TR & 9.14 & 10.26 & 11.85 & 11.86 & 11.98 & 11.02 & 8.10 & 9.03 & 6.79 & 5.31 & 4.19 & 6.68 & 4.33 \\
\hline 18 ABM & 6.71 & 5.96 & 5.76 & 11.29 & 5.09 & 6.96 & 7.72 & 8.31 & 7.54 & 5.60 & 4.95 & 6.82 & 0.14 \\
\hline $\begin{array}{ll}19 \mathrm{CWT} \\
\end{array}$ & 6.31 & 6.72 & 5.34 & 5.27 & 6.13 & 5.95 & 5.76 & 7.27 & 5.90 & 4.73 & 4.55 & 5.64 & 0.31 \\
\hline $20 \mid$ SJW & 5.02 & 8.75 & 6.39 & 6.88 & 7.00 & 6.81 & 5.55 & 5.82 & 4.58 & 2.76 & 1.99 & 4.14 & 2.67 \\
\hline $21 \mid$ FRT & 7.07 & 6.99 & 7.11 & 6.95 & 6.32 & 6.89 & 6.17 & 4.53 & 4.00 & 3.88 & 4.00 & 4.52 & 2.37 \\
\hline 22 SWK & 10.64 & 11.65 & 13.05 & 14.16 & 13.95 & 12.69 & 10.73 & 7.24 & 6.09 & 8.77 & 9.20 & 8.41 & 4.28 \\
\hline \begin{tabular}{l|l|l|}
23 & $\mathrm{SCL}$ \\
\end{tabular} & 14.17 & 8.83 & 12.32 & 14.01 & 13.44 & 12.55 & 7.08 & 5.69 & 9.08 & 10.44 & 10.56 & 8.57 & 3.98 \\
\hline 24 TGT & 11.27 & 10.15 & 11.55 & 14.34 & 15.61 & 12.58 & 4.36 & 6.13 & 6.61 & 5.03 & 5.05 & 5.44 & 7.15 \\
\hline 25 MO & 35.72 & 33.30 & 39.15 & 32.89 & 39.83 & 36.18 & 5.01 & 6.23 & 7.22 & 5.62 & 4.95 & 5.81 & 30.37 \\
\hline 26 CTWS & 7.84 & 6.59 & 6.68 & 6.28 & 6.57 & 6.79 & 4.41 & 4.71 & 3.63 & 2.78 & 2.80 & 3.67 & 3.13 \\
\hline 27 FUL & 11.30 & 6.37 & 7.08 & 9.47 & 4.44 & 7.73 & 10.03 & 12.15 & 10.90 & 10.00 & 9.01 & 10.42 & -2.69 \\
\hline \begin{tabular}{|l|l|}
$28 \mathrm{SYY}$ \\
\end{tabular} & 14.49 & 13.14 & 11.11 & 16.84 & 15.75 & 14.27 & 6.62 & 6.93 & 6.40 & 4.09 & 4.42 & 5.69 & 8.57 \\
\hline $29 \mathrm{BKH}$ & 6.40 & 6.13 & 6.54 & 6.00 & 6.07 & 6.23 & 5.72 & 6.28 & 6.67 & 5.12 & 3.76 & 5.51 & 0.72 \\
\hline 30 NFG & 8.60 & 8.86 & 6.92 & 7.90 & 10.06 & 8.47 & 10.69 & 9.83 & 6.93 & 5.19 & 5.88 & 7.70 & 0.76 \\
\hline 31 UW & 10.65 & 7.47 & 8.10 & 8.01 & 7.99 & 8.44 & 7.27 & 7.98 & 8.68 & 8.05 & 8.23 & 8.04 & 0.40 \\
\hline $\begin{array}{ll}32 \mathrm{BDX} \\
\end{array}$ & 15.98 & 19.72 & 11.37 & 10.86 & 11.73 & 13.93 & 7.26 & 7.41 & 8.41 & 6.52 & 7.22 & 7.36 & 6.57 \\
\hline \begin{tabular}{l|l|}
33 & $\operatorname{csV}$ \\
\end{tabular} & 21.32 & 20.91 & 21.18 & 21.47 & 22.53 & 21.48 & 0.00 & 4.53 & 4.41 & 1.84 & 3.51 & 2.86 & 18.62 \\
\hline $34 \mid$ KMB & 19.72 & 18.39 & 15.43 & 32.96 & 33.80 & 24.06 & 3.43 & 4.75 & 6.59 & 5.62 & 6.06 & 5.29 & 18.77 \\
\hline $35 \mid$ LEG & 12.28 & 13.19 & 20.05 & 20.53 & 16.45 & 16.50 & 6.99 & 6.68 & 8.20 & 8.23 & 6.95 & 7.41 & 9.09 \\
\hline 36 MSA & 14.19 & 13.58 & 10.62 & 12.39 & 6.59 & $\begin{array}{ll}11.47 \\
\end{array}$ & 11.41 & 9.11 & 11.70 & 11.46 & 11.21 & 10.98 & 0.50 \\
\hline 37) PEP & 16.75 & 17.49 & 20.22 & 22.34 & 17.11 & 18.78 & 4.37 & 4.18 & 6.04 & 5.72 & 5.46 & 5.15 & 13.63 \\
\hline \begin{tabular}{|l|l|}
38 & PPG \\
\end{tabular} & 19.82 & 20.31 & 18.81 & 10.74 & 17.68 & 17.47 & 9.57 & 7.22 & 10.84 & 11.01 & 10.84 & 9.90 & 7.58 \\
\hline \begin{tabular}{l|l|l|}
39 & TNC
\end{tabular} & 19.59 & 24.40 & 18.56 & 19.96 & 29.73 & 22.45 & 8.41 & 7.09 & 6.71 & 8.41 & 8.71 & 7.87 & 14.58 \\
\hline $40 \mathrm{GWW}$ & 24.40 & 23.50 & 21.50 & 17.53 & 18.08 & 21.00 & 7.54 & 8.80 & 6.21 & 5.85 & 5.45 & 6.77 & 14.23 \\
\hline 41 GRC & 11.92 & 14.02 & 9.20 & 10.06 & 11.52 & 11.34 & 8.79 & 7.40 & 9.90 & 11.44 & 10.69 & 9.64 & 1.70 \\
\hline \begin{tabular}{l|l|l|}
42 & $\mathrm{HP}$ \\
\end{tabular} & 14.87 & 15.17 & 9.59 & -0.49 & -3.27 & 7.17 & 13.20 & 11.10 & 7.86 & 8.67 & 9.35 & 10.04 & -2.86 \\
\hline \begin{tabular}{|l|l|}
43 MSEX \\
\end{tabular} & 5.83 & 6.34 & 6.68 & 7.50 & 6.75 & 6.62 & 5.11 & 4.36 & 4.74 & 5.32 & 4.29 & 4.76 & 1.86 \\
\hline $44 \mid \mathrm{SPGI}$ & 52.10 & -83.22 & 90.86 & 61.53 & 101.86 & 44.63 & 8.03 & 11.22 & 10.72 & 10.13 & 10.54 & 10.13 & 34.50 \\
\hline $\begin{array}{l}45 \mid \text { VFC } \\
\end{array}$ & 19.44 & 21.69 & 20.65 & 19.73 & 12.64 & 18.83 & 6.30 & 7.22 & 7.69 & 6.39 & 6.17 & 6.75 & 12.08 \\
\hline \begin{tabular}{l|l|}
46 & WMT \\
\end{tabular} & 15.26 & 13.94 & 14.29 & 13.34 & 12.98 & 13.96 & 3.96 & 4.39 & 3.29 & 3.15 & 2.49 & 3.46 & 10.51 \\
\hline $\begin{array}{l}47 \\
\text { ED } \\
\end{array}$ & 6.68 & 5.88 & 6.29 & 5.68 & 6.58 & 6.22 & 3.19 & 3.54 & 3.23 & 2.80 & 2.34 & 3.02 & 3.20 \\
\hline \begin{tabular}{l|l|l|}
$48 P M$ \\
\end{tabular} & 9.12 & 14.09 & 9.76 & 15.10 & 13.25 & 12.26 & 8.74 & 8.80 & 8.89 & 8.88 & 10.17 & 9.10 & 3.17 \\
\hline \begin{tabular}{ll|}
49 & ADM \\
\end{tabular} & 5.64 & 8.65 & 6.94 & 5.08 & 6.25 & 6.51 & 8.63 & 5.31 & 8.54 & 7.86 & 7.48 & 7.56 & -1.05 \\
\hline \begin{tabular}{|l|l|}
50 & ADP \\
\end{tabular} & 24.24 & 31.82 & 43.07 & 45.39 & 49.05 & 38.71 & 7.82 & 7.69 & 8.48 & 6.32 & 6.95 & 7.45 & 31.26 \\
\hline $51 \mid \mathrm{ITW}$ & 13.83 & 17.83 & 20.21 & 22.36 & 18.55 & 18.56 & 9.25 & 7.00 & 7.64 & 8.90 & 8.74 & 8.31 & 10.25 \\
\hline 52 MCD & 21.50 & 19.39 & 20.64 & 23.18 & 21.93 & 21.33 & 4.60 & 5.61 & 6.19 & 6.19 & 6.36 & 5.79 & 15.54 \\
\hline 53 MGEE & 8.67 & 8.84 & 7.86 & 8.14 & 9.94 & 8.69 & 5.20 & 6.16 & 4.37 & 3.52 & 2.01 & 4.25 & 4.44 \\
\hline 54 PNR & 6.53 & 5.08 & 5.92 & 6.69 & 9.11 & 6.67 & 8.61 & 8.37 & 7.25 & 7.52 & 7.88 & 7.93 & -1.26 \\
\hline \begin{tabular}{l|l|l|} 
WBA \\
\end{tabular} & 10.07 & 9.11 & 10.71 & 11.70 & 11.81 & 10.68 & 10.05 & 7.85 & 11.68 & 7.35 & 7.20 & 8.83 & 1.85 \\
\hline $56 \mid \mathrm{CSL}$ & 11.75 & 12.99 & 14.02 & 13.21 & 12.30 & 12.85 & 12.07 & 7.55 & 7.07 & 6.88 & 5.56 & 7.83 & 5.03 \\
\hline $57 \mid \operatorname{CLX}$ & 28.57 & 29.13 & 32.37 & 33.67 & 33.58 & 31.46 & 4.54 & 4.89 & 5.17 & 3.35 & 3.64 & 4.32 & 27.15 \\
\hline 58 WGL & 4.61 & 5.50 & 6.41 & 6.62 & 6.05 & 5.84 & 5.11 & 6.60 & 5.41 & 3.61 & 3.72 & 4.89 & 0.95 \\
\hline $\begin{array}{l}59 \mid \text { MDT } \\
\end{array}$ & 21.48 & 22.69 & 8.05 & 6.93 & 7.85 & 13.40 & 8.51 & 7.33 & 7.88 & 6.43 & 5.31 & 7.09 & 6.31 \\
\hline 60 SHW & 29.91 & 33.27 & 41.22 & 44.39 & 25.11 & 34.78 & 5.73 & 4.45 & 9.35 & 10.44 & 10.40 & 8.07 & 26.71 \\
\hline
\end{tabular}


The analysis shows that:

- 56 out of the 60 companies have an average ROIC greater than their average WACC; and

- 4 out of the 60 companies have an average ROIC less than their average WACC.

Therefore, in percentage terms, $93 \%$ of the sample examined has an average ROIC value higher than the average WACC.

In the next phase, after having extracted the Competitors of the "Dividend Champions" in the US market, according to their sectors (Damodaran Online, 2018), we found the ROIC and WACC for these companies for the last 5 years (2013-2017) and we determined the average ROIC and WACC of the Competitors (Table 4).

Table 4. ROIC - WACC Analysis for competitors in the US market

\begin{tabular}{|c|c|c|c|c|c|c|c|c|c|c|c|c|c|c|}
\hline Industry Name & Number of Firms & Roic 2013 & Roic 2014 & Roic 2015 & Roic 2016 & Roic 2017 & Average Roic & Wacc 2013 & Wacc 2014 & Wacc 2015 & Wacc 201 & Wacc 2017 & verage & Roic-Wacc \\
\hline Apparel & 51 & $22.17 \%$ & $18.12 \%$ & $15.99 \%$ & $14.81 \%$ & $14.18 \%$ & $17.05 \%$ & $8.18 \%$ & $15.99 \%$ & $14.81 \%$ & $14.18 \%$ & $6.40 \%$ & $11.91 \%$ & $5.14 \%$ \\
\hline Beverage (Soft) & 35 & $27.28 \%$ & $27.58 \%$ & $22.42 \%$ & $25.31 \%$ & $24.92 \%$ & $25.50 \%$ & $9.54 \%$ & $22.42 \%$ & $25.31 \%$ & $24.92 \%$ & $5.42 \%$ & $17.52 \%$ & $7.98 \%$ \\
\hline Brokerage \& Investment Banking & 42 & $0.29 \%$ & $0.02 \%$ & $0.00 \%$ & $-0.01 \%$ & $0.02 \%$ & $0.06 \%$ & $5.55 \%$ & $0.00 \%$ & $-0.01 \%$ & $0.02 \%$ & $4.76 \%$ & $2.07 \%$ & $2.00 \%$ \\
\hline Business \& Consumer Services & 169 & $23.39 \%$ & $23.95 \%$ & $22.41 \%$ & $23.85 \%$ & $26.37 \%$ & $23.99 \%$ & $6.91 \%$ & $22.41 \%$ & $23.85 \%$ & $26.37 \%$ & $7.19 \%$ & $17.34 \%$ & $6.65 \%$ \\
\hline Chemical (Basic) & 38 & $14.86 \%$ & $18.04 \%$ & $12.57 \%$ & $14.85 \%$ & $14.43 \%$ & $14.95 \%$ & $7.76 \%$ & $12.57 \%$ & $14.85 \%$ & $14.43 \%$ & $6.88 \%$ & $11.30 \%$ & $3.65 \%$ \\
\hline Computer Services & 111 & $57.15 \%$ & $37.39 \%$ & $30.10 \%$ & $29.66 \%$ & $27.96 \%$ & $36.45 \%$ & $7.27 \%$ & $30.10 \%$ & $29.66 \%$ & $27.96 \%$ & $6.82 \%$ & $20.36 \%$ & $16.09 \%$ \\
\hline Diversified & 24 & $4.94 \%$ & $7.66 \%$ & $7.71 \%$ & $8.08 \%$ & $10.98 \%$ & $7.87 \%$ & $5.47 \%$ & $7.71 \%$ & $8.08 \%$ & $10.98 \%$ & $7.07 \%$ & $7.86 \%$ & $0.01 \%$ \\
\hline Healthcare Products & 251 & $14.47 \%$ & $16.05 \%$ & $16.75 \%$ & $16.50 \%$ & $16.30 \%$ & $16.01 \%$ & $7.79 \%$ & $16.75 \%$ & $16.50 \%$ & $16.30 \%$ & $6.66 \%$ & $12.80 \%$ & $3.21 \%$ \\
\hline Healthcare Support Services & 115 & $38.67 \%$ & $37.10 \%$ & $41.50 \%$ & $41.84 \%$ & $50.54 \%$ & $41.93 \%$ & $6.77 \%$ & $41.50 \%$ & $41.84 \%$ & $50.54 \%$ & $6.17 \%$ & $29.36 \%$ & $12.57 \%$ \\
\hline Office Equipment \& Services & 24 & $24.24 \%$ & $21.41 \%$ & $23.02 \%$ & $22.72 \%$ & $17.72 \%$ & $21.82 \%$ & $7.37 \%$ & $23.02 \%$ & $22.72 \%$ & $17.72 \%$ & $7.20 \%$ & $15.60 \%$ & $6.22 \%$ \\
\hline Oil/Gas Distribution & 16 & $10.78 \%$ & $10.27 \%$ & $9.21 \%$ & $7.37 \%$ & $6.13 \%$ & $8.75 \%$ & $6.18 \%$ & $9.21 \%$ & $7.37 \%$ & $6.13 \%$ & $5.85 \%$ & $6.95 \%$ & $1.81 \%$ \\
\hline Packaging \& Container & 25 & $18.14 \%$ & $19.48 \%$ & $17.10 \%$ & $14.74 \%$ & $14.58 \%$ & $16.81 \%$ & $6.52 \%$ & $17.10 \%$ & $14.74 \%$ & $14.58 \%$ & $5.02 \%$ & $11.59 \%$ & $5.22 \%$ \\
\hline R.E.I.T. & 244 & $0.01 \%$ & $2.56 \%$ & $2.73 \%$ & $3.01 \%$ & $3.08 \%$ & $2.28 \%$ & $4.80 \%$ & $2.73 \%$ & $3.01 \%$ & $3.08 \%$ & $4.43 \%$ & $3.61 \%$ & $-1.33 \%$ \\
\hline Restaurant/Dining & 81 & $16.51 \%$ & $15.09 \%$ & $15.87 \%$ & $15.88 \%$ & $17.01 \%$ & $16.07 \%$ & $6.66 \%$ & $15.87 \%$ & $15.88 \%$ & $17.01 \%$ & $5.81 \%$ & $12.25 \%$ & $3.83 \%$ \\
\hline Retail (Distributors) & 92 & $15.52 \%$ & $14.87 \%$ & $13.74 \%$ & $12.84 \%$ & $13.18 \%$ & $14.03 \%$ & $7.00 \%$ & $13.74 \%$ & $12.84 \%$ & $13.18 \%$ & $6.59 \%$ & $10.67 \%$ & $3.36 \%$ \\
\hline Retail (General) & 18 & $13.23 \%$ & $12.10 \%$ & $12.46 \%$ & $11.57 \%$ & $11.90 \%$ & $12.25 \%$ & $6.84 \%$ & $12.46 \%$ & $11.57 \%$ & $11.90 \%$ & $6.61 \%$ & $9.88 \%$ & $2.37 \%$ \\
\hline Rubber \& Tyres & 4 & $23.80 \%$ & $21.62 \%$ & $20.05 \%$ & $17.60 \%$ & $13.96 \%$ & $19.40 \%$ & $7.59 \%$ & $20.05 \%$ & $17.60 \%$ & $13.96 \%$ & $5.38 \%$ & $12.91 \%$ & $6.49 \%$ \\
\hline Tobacco & 24 & $109.73 \%$ & $100.07 \%$ & $77.34 \%$ & $60.73 \%$ & $95.59 \%$ & $88.69 \%$ & $7.07 \%$ & $77.34 \%$ & $60.73 \%$ & $95.59 \%$ & $7.97 \%$ & $49.74 \%$ & $38.95 \%$ \\
\hline Utilities (General) & 18 & $6.93 \%$ & $-12.18 \%$ & $-3.01 \%$ & $6.81 \%$ & $6.21 \%$ & $0.95 \%$ & $4.61 \%$ & $-3.01 \%$ & $6.81 \%$ & $6.21 \%$ & $3.28 \%$ & $3.58 \%$ & $-2.63 \%$ \\
\hline
\end{tabular}

Finally, we performed a comparative analysis between the ROIC and WACC of the "Dividend Champions" and those of their respective Competitors (Table 5), in each of the 19 sectors.

Table 5: Analysis of ROIC - WACC for "Dividend Champions" vs. US Market Competitors

\begin{tabular}{|c|c|c|c|c|}
\hline Industry Name & Dividend Champions Firms & Roic - Wacc Dividend Champions & Competitors Firms & Roic -Wacc Competitors \\
\hline Apparel & 4 & $9.04 \%$ & 51 & $5.14 \%$ \\
\hline Beverage (Soft) & 2 & $10.74 \%$ & 35 & $7.98 \%$ \\
\hline Brokerage \& Investment Banking & 1 & $34.50 \%$ & 169 & $-2.00 \%$ \\
\hline Business \& Consumer Services & 2 & $15.70 \%$ & 38 & $6.65 \%$ \\
\hline Chemical (Basic) & 5 & $7.75 \%$ & 111 & $3.65 \%$ \\
\hline Computer Services & 1 & $18.62 \%$ & 24 & $16.09 \%$ \\
\hline Diversified & 10 & $6.79 \%$ & 251 & $0.01 \%$ \\
\hline Healthcare Products & 2 & $11.50 \%$ & 115 & $3.21 \%$ \\
\hline Healthcare Support Services & 1 & $6.57 \%$ & 24 & $12.57 \%$ \\
\hline Office Equipment \& Services & 1 & $0.50 \%$ & 16 & $6.22 \%$ \\
\hline Oil/Gas Distribution & 2 & $-1.05 \%$ & 25 & $1.81 \%$ \\
\hline Packaging \& Container & 8 & $15.65 \%$ & 244 & $5.22 \%$ \\
\hline R.E.I.T. & 1 & $2.37 \%$ & 81 & $-1.33 \%$ \\
\hline Restaurant/Dining & 1 & $15.54 \%$ & 92 & $3.83 \%$ \\
\hline Retail (Distributors) & 1 & $14.23 \%$ & 18 & $3.36 \%$ \\
\hline Retail (General) & 4 & $7.02 \%$ & 4 & $2.37 \%$ \\
\hline Rubber \& Tyres & 1 & $5.03 \%$ & 24 & $6.49 \%$ \\
\hline Tobacco & 2 & $15.39 \%$ & 18 & $38.95 \%$ \\
\hline Utilities (General) & 11 & $2.15 \%$ & & $-2.63 \%$ \\
\hline
\end{tabular}


From the analysis (Table 5) it emerges, with reference to the "Dividend Champions", that:

- In 14 sectors out of 19, the ROIC - WACC spread is higher for the "Dividend Champions" than for the Competitors; and

- In 5 sectors out of 19, the ROIC - WACC spread is lower for the "Dividend Champions" than for the Competitors.

Table 6. Competitive advantage analysis by sector

\begin{tabular}{|c|c|c|c|}
\hline Industry Name & Roic - Wacc Dividend Champions & Roic -Wacc Competitors & Competitive Advantage \\
\hline Apparel & $9.04 \%$ & $5.14 \%$ & Yes \\
\hline Beverage (Soft) & $10.74 \%$ & $7.98 \%$ & Yes \\
\hline Brokerage \& Investment Banking & $34.50 \%$ & $-2.00 \%$ & Yes \\
\hline Business \& Consumer Services & $15.70 \%$ & $6.65 \%$ & Yes \\
\hline Chemical (Basic) & $7.75 \%$ & $3.65 \%$ & Yes \\
\hline Computer Services & $18.62 \%$ & $16.09 \%$ & Yes \\
\hline Diversified & $6.79 \%$ & $0.01 \%$ & Yes \\
\hline Healthcare Products & $11.50 \%$ & $3.21 \%$ & No \\
\hline Healthcare Support Services & $6.57 \%$ & $12.57 \%$ & No \\
\hline Office Equipment \& Services & $0.50 \%$ & $6.22 \%$ & Yes \\
\hline Oil/Gas Distribution & $-1.05 \%$ & $1.81 \%$ & Yes \\
\hline Packaging \& Container & $15.65 \%$ & $5.22 \%$ & Yes \\
\hline R.E.I.T. & $2.37 \%$ & $-1.33 \%$ & Yes \\
\hline Restaurant/Dining & $15.54 \%$ & $3.83 \%$ & Yes \\
\hline Retail (Distributors) & $14.23 \%$ & $3.36 \%$ & No \\
\hline Retail (General) & $7.02 \%$ & $2.37 \%$ & No \\
\hline Rubber \& Tyres & $5.03 \%$ & $6.49 \%$ & Yes \\
\hline Tobacco & $15.39 \%$ & $38.95 \%$ & $-2.63 \%$ \\
\hline Utilities (General) & $2.15 \%$ & & \\
\hline
\end{tabular}

We can observe that the "Dividend Champions", classified by sector, show, when compared to the main competitors of reference in the US market, a lasting competitive advantage based on their profitability: the ROIC is higher, on average, than the cost of capital. We can consequently conclude that the "Dividend Champions", classified by sector, are also "Value Champions": they are able to beat their competitors, and they have a lasting competitive advantage.

\section{Conclusions}

To our knowledge, this is one of the first exploratory studies on so-called "Dividend Champions" (Miglietta et al., 2017, 2018a), companies that for over 40 years have systematically distributed growing dividends, performed on the basis of a comparison between ROIC and WACC as an indicator of value creation (Adams and Thornton, 2009; Lin and Huang, 2011).

Concretely, the aim of this work was to investigate, through the measurement of value creation, the existence of a competitive advantage in the "Dividend Champions" in the S\&P 500.

The study shows that the above companies, which distribute increasing dividends and, at the same time, have a greater ROIC than WACC, can also be called "Value Champions": they are companies with a lasting competitive advantage. The results of our research show that the "Dividend Champions" have a lasting competitive advantage, on the basis of their profitability, which was, on average, higher than their cost of capital. In fact, the literature affirms that the creation of value for shareholders requires a sustainable competitive advantage over time (e.g. Barney, 1991, 2001; Copeland et al., 1990; Porter, 1988; Rappaport, 1986).

In particular, our research highlights are as follows:

- $\quad 93 \%$ of the "Dividend Champions" examined create value, presenting a return on invested capital greater than the average cost of the various sources of financing used; and

- $88 \%$ of the "Dividend Champions" create more value than their competitors and therefore have a lasting competitive advantage and can be identified as "Value Champions".

Our results offer some interesting implications for theory and practice. Concerning the theoretical implications, 
we connect the value creation and the competitive advantage to the companies called "Dividend Champions" and, to the authors' knowledge, this is the first exploratory study based on these integrated topics. Regarding the practical implications, this research is useful for investors who intend to invest in a companies that have specific characteristics from the point of view of lasting competitive advantage.

The limits of this first exploratory study are as follows:

- The different number of companies belonging to each of the sectors analysed, both the different numbers of "Dividend Champions" and the different numbers of competitors, does not allow a generalization of the results achieved;

- A different time horizon in which the value creation of "Dividend Champions" was measured could have been chosen; and

- Not having considered innovation, understood as a product, process or technological innovation, as a factor that can strongly influence the determination whether a company enjoys a competitive advantage or not.

Future works could be based:

- On an analysis within each sector to discover the firms called "Value Champions";

- On an observation of other factors such as innovation and human resources to understand whether they influence a company's ability to hold a competitive advantage over others; and

- On an observation of pricing, to understand if the companies called "Dividend Champions" are under or overvalued.

\section{References}

Adams, M., \& Thornton, B. (2009). A Comparison of Alternative Approaches to Equity Valuation of Privately Held Entrepreneurial Firms. Journal of Finance and Accountancy, 1, 2-15.

Argote, L., \& Ingram, P. (2000). Knowledge transfer: A basis for competitive advantage in firms. Organizational Behavior and Human Decision Processes, 82(1), 150-169.

Baker, H. K, Farrelly, G. E., \& Edelman, R. B. (1985). A Survey of Management Views on Dividend Policy. Financial Management, 14(3), 78-84.

Baker, H. K, Velt, E. T., \& Powell, G. E. (2001). Factors Influencing Dividend Policy Decisions. Financial Practice and Education, 6(3), 19-38.

Barney, J. B. (1991). Firm resource and sustained competitive advantage. Journal of Management, 17(1), 99-120.

Barney, J. B. (2001). Resource-based theories of competitive advantage: A ten-year retrospective on the resource-based view. Journal of management, 27(6), 643-650.

Benartzi, S, Michaely, R., \& Thaler, R. (1997). Do Changes in Dividends Signal the Future or the Past?. The Journal of Finance, 52(3), 1007-1034.

Berk, J., \& DeMarzo, P. (2008). Finanza Aziendale 2, Addison Wesley: Pearson Education.

Bhattacharya, S. (1979). Imperfect information, dividend policy and the 'bird in the hand' fallacy. Bell Journal of Economics, 10(1), 259-70.

Black, F., \& Scholes, M. (1974). The Effects of Dividend Yield and Dividend Policy on Common Stock Prices and Returns. Journal of Financial Economics, 1(1), 1-22.

Blyth, M. L., Friskey, E. A., \& Rappaport, A. (1986). Implementing the shareholder value approach. Journal of Business Strategy, 6(3), 48-58.

Brealey, R., Myers, S., Allen, F., \& Sandri, S. (2015). Principi di finanza aziendale. Milano: McGraw-Hill.

Bughin, J., \& Copeland, T. E. (1997). The virtuous cycle of shareholder value creation. McKinsey Quarterly, 2, $157-167$.

Burns, R. (2000). Introduction to Research Methods. Sage: London.

Copeland, T. E, Koller, T., \& Murrin, J. (1990). Valuation: Measuring and Managing the Value of Companies, New York: Wiley.

Copeland, T. E. (2002a). Want to create value? Strategic Finance, 3(9), 48-54. 
Copeland, T. E. (2002b). What do practitioners want?. Journal of Applied Finance, 12(1), 5-12.

Dallocchio, M., \& Salvi, A. (2011). Finanza aziendale 1. Milano: Egea.

Damodaran, A. (2001). Corporate Finance: Theory and Practice. Chichester: Wiley.

Damodaran, A. (2015). Applied Corporate Finance. Chichester: Wiley.

Damodaran, A. (2018). Damodaran Online. Retrieved from http://pages.stern.nyu.edu/ adamodar/

Fama, E., \& Babiak, H. (1968). Dividend Policy: An Empirical Analysis. Journal of the American Statistical Association, 63(324), 1132-1161.

Farrelly, G., Baker, K., \& Edehan, R. (1986). Corporate Dividends: Views of the Policymakers. Akron Business and Economic Review, 17(4), 62-74.

Ferrero, G. (1981). Finanza aziendale. Milano: Giuffré Editore.

Fontana, F., \& Caroli, M. (2009). Economia e gestione delle imprese. New York: McGraw-Hill

Ghemawat, P. (1991). Commitment: The Dynamic of Strategy. Boston: Free Press.

Grant, R. M. (1995). Contemporary strategy analysis. Hoboken: Blackwell Pub.

Grant, R. M. (1999). The resource-based theory of competitive advantage: implications for strategy formulation, Knowledge and strategy, 33(3), 3-23.

Guatri, L. (1991). La Teoria di Creazione del Valore. Una via Europea. Milano: Egea

Hall, R. (1993). A framework linking intangible resources and capabilities to sustainable competitive advantage. Strategic management journal, 14(8), 607-618.

Hawawini, G., Subramanian, V., \& Verdin, P. (2002). Is performance driven by industry or firm specific factors? A new look at the evidence. Strategic Management Journal, 24(1), 1-16.

Healy, P., \& Palepu, K. (1988). Earnings information conveyed by dividend initiations and omissions. Journal of financial Economics, 21(2), 149-175.

Jensen, M. C. (2001). Value Maximization, stakeholder Theory, and the Corporate Objective Function. Journal of Applied Corporate Finance, 14(3), 8-21.

Jose, M. L., \& Stevens J. L. (1989). Capital Market Valuation of Dividend Policy. Journal of Business Finance \& Accounting, 16(5), 651-662.

Kay, J. (1993). Foundations of Corporate Success: How Business Strategies Add Value. New York: Oxford University Press.

Lin, C. S., \& Huang, C. P. (2011). Measuring competitive advantage with an asset-light valuation model. African Journal of Business Management, 5(13), 5100-5108.

Lintner, J. (1956). Distribution of Incomes of Corporations among Dividends, Retained Earnings, and Taxes. The American Economic Review, 46(2), 97-113.

Miglietta, N., Battisti, E., \& Campanella, F. (2017). Value maximization and open innovation in food and beverage industry: evidence from US market. British Food Journal, 119(11), 2477-2492.

Miglietta, N., Battisti, E., \& Garcia-Perez, A. (2018a). Shareholder value and open innovation: evidence from Dividend Champions. Management Decision, 56(6), 1384-1397.

Miglietta, N., Battisti, E., Carayannis, E., \& Salvi, A. (2018b). Capital structure and business process management: evidence from ambidextrous organizations. Business Process Management Journal, 24(5), 1255-1270.

Miller, M. H., \& Scholes, M. (1978). Dividends and Taxes. Journal of Financial Economics, 6(4), 333-64.

Modigliani, F., \& Miller M. H. (1961). Dividend Policy, Growth and the Valuation for Shares. The Journal of Business, 34(4), 411-433.

Pellicelli, G. (2014). Strategie d'impresa. Milano: Egea.

Pivato, S., Misani, N., Ordanini, A., \& Perrini, F. (2004). Economia e gestione delle imprese. Milano: Egea.

Porter, M.E. (1998). Competitive Strategy Boston: Free Press.

Pruitt, W., \& Gitman, L. (1991). The Interactions between the Investment, Financing, and Dividend Decisions of Major US. Firms. Financial Review, 26(3), 409-430. 
Punch, K. (1998). Introduction to Social Research: Quantitative and Qualitative Approaches. London: Sage. Rappaport, A. (1986). Creating Shareholder Value. New York: Free Press.

Tang, Y.C., \& Liou, F.M. (2010). Does firm performance reveal its own causes? The role of Bayesian inference. Strategic Management Journal, 31(1), 39-57.

Tardivo, G., Schiesari, R., \& Miglietta, N. (2010). Finanza aziendale. Torino: Isedi.

Tobin, J. (1969). A General Equilibrium Approach to Monetary Theory. Journal of Money, Credit and Banking, l(1), 15-29.

Ubago Vivas, J. N. (2014). Analisi Finanziaria. Milano: Ipsoa.

Watson, D., \& Head, A. (2016). Corporate Finance: principle and practice. New York: Pearson.

Watts, R. (1973). The information content of dividends. The Journal of Business, 46(2), 191-211.

\section{Copyrights}

Copyright for this article is retained by the author(s), with first publication rights granted to the journal.

This is an open-access article distributed under the terms and conditions of the Creative Commons Attribution license (http://creativecommons.org/licenses/by/4.0/). 